\title{
On the Precedence of Constraints on Growth: Advocating the Ecological Footprint Perspective
}

\author{
Carlos Guerrero de Lizardi ${ }^{1}$ - Universidad Nacional Autónoma de México, México
}

Our goal is to propose the ecological footprint as the first growth restriction that currently faces the Mexican economy. To capture the attention of both orthodox and heterodox economists, we will analyze three restrictions on growth, namely, on the supply, demand, and biocapacity side. Our first recommendation highlights the need for Mexico to fully redesign its public policies in order to substantially improve its results in terms of environmental sustainability hand in hand with a much better distribution of income and wealth. A limitation lies in the review of only the neoclassical and post-Keynesian growth theories, involving a personal selection from the literature. As far as we know, this document represents the first study that incorporates within the theories of economic growth the restriction linked to biocapacity and the ecological footprint in Mexico. The main conclusion constitutes a local echo of world literature - the immediate challenge facing Mexico and other societies is to make any economic-social result compatible with a single earth planet.

JEL Classification: E12, C50, P10.

Keywords: neoclassical growth theory, third-generation post-Keynesian growth theory, environmental sustainability, social responsibility.

\section{Sobre la prelación de las restricciones al crecimiento económico: abogando por la perspectiva basada en la huella ecológica}

Nuestro objetivo es proponer la huella ecológica como la primera restricción al crecimiento que enfrenta actualmente la economía mexicana. Para captar la atención de economistas ortodoxos y heterodoxos, analizaremos tres restricciones al crecimiento, a saber, por el lado de la oferta, la demanda y la biocapacidad. Nuestra primera recomendación destaca la necesidad de que México rediseñe completamente sus políticas públicas a fin de mejorar sustancialmente sus resultados en términos de sustentabilidad ambiental de la mano de una mucho mejor distribución del ingreso y la riqueza. Una limitación radica en la revisión de solo las teorías del crecimiento neoclásica y postkeynesiana, lo que implica una selección personal de la literatura. Hasta donde sabemos, este documento representa el primer estudio que incorpora dentro de las teorías del crecimiento económico la restricción ligada a la biocapacidad y la huella ecológica en México. La principal conclusión constituye un eco local de la literatura mundial: el desafío inmediato que enfrentan México y otras sociedades es compatibilizar cualquier resultado económico-social con un solo planeta tierra.

Clasificación JEL: E12, C50, P10.

Palabras clave: teoría del crecimiento neoclásica, teoría postkeynesiana de tercera generación, sustentabilidad ambiental, responsabilidad social.

\footnotetext{
${ }^{1}$ Corresponding author. Email: cguerrero@economia.unam.mx

* No source of funding for research development
} 
"Degrowth: a planned reduction of excess energy and resource use in rich nations to bring the economy back into balance with the living world, while reducing inequality and improving people's access to the resources they need to live long, healthy, flourishing lives." Jason Hickel (Less is More: How Degrowth will Save the World, 2020).

\section{Introduction}

Our goal is to propose the ecological footprint as the first growth restriction that currently faces the Mexican economy -and by extension, other countries. To capture the attention of both orthodox and heterodox economists, we will follow a three-step strategy. Following the OECD (2020) we will carry out an analysis using the theoretical framework of the aggregate production function. Later we will use the framework preferred by heterodox economists, namely, the growth restriction on the balance of payments side. Having caught, hopefully, the attention of the average economist, following Sharif, Baris-Tuzemen, Uzuner, Ozturk and Sinha (2020) among others, we will analyze the biocapacity as the first limitation to growth. We will take as a reference point the updated goal proposed by the Ministry of Finance and Public Credit for the period 2019-2024, that is, 0.74 percent annual average (SHCP, 2020).

Based on the seminal ideas of Nobel Solow, we performed a couple of simulations to explore whether the Mexican economy will face a restriction on the supply side. To the scenario proposed by the SHCP, we add another of "accelerated" growth. Despite the deterioration of productive capacities during 2020, the six-year goal proposed by the SHCP seems achievable in terms of changes in the capital stock in use -under the assumption of the application of a package of unconventional active economic policies. In contrast, our 4 percent growth scenario seems unattainable.

To the extent the Monthly Business Opinion Survey reports a very low capacity utilization since the last major global crisis, that is, an average of 51.42 percent between January 2009 and September 2020, it is worth exploring the restriction on the demand side. Specifically, we will use a third-generation post-Keynesian perspective (Moreno-Brid and Pérez, 2003; Guerrero, 2006). Our main result can be summarized as follows: considering the estimated ratio of income elasticities of exports and imports, if the growth of manufacturing GDP in the United States in the coming years is similar to that observed in its recent history, and considering the performance under the current lockdown and the "stay-at-home" order (BEA, 2020, p. 1), then the growth of the Mexican economy would be around one percentage point during the next years.

The third growth constraint analyzed makes intensive use of the Global Footprint Network perspective (Wackernagel, Beyers, and Rout, 2019). Its relevance is absolutely beyond question -for example, Sharif, Baris-Tuzemen, Uzuner, Ozturk, and Sinha recently wrote (2020, p. 5):

"It is possible to find several articles on the relation among energy consumption, environmental degradation and economic growth. These studies can be categorized by three main groups. The first group studies are the ones that focus on the connection between energy (electricity) consumption and economic growth... The second group tested the link between economic growth and carbon dioxide emissions as a proxy of 
environmental degradation... Finally, the third category merges the first two groups into the survey of the relation among economic growth, environmental degradation (and ecological footprint) and energy use by source namely renewable and non-renewable."

To introduce the ecological perspective, we have to recognize the following three definitions. The first is biocapacity, that is, our planet's biological power to regenerate and reproduce plant matter. By the way, this primary productivity of nature is the source for all life, including human life. The second is the ecological footprint, which accounts for our use of biocapacity and our environmental impacts due to waste management -and depends on the technologies in use. The third definition is their difference, which is labeled as surplus or deficit. The entire world has accumulated a growing deficit since the early 1970s, and Mexico in particular since the middle of the same decade.

At the end of the document, we will share some conclusions, among others the following. First, the only constraint that questions the very existence of societies as we know them today is the one linked to the environment. The reason is simple, economic growth around the world has been for five long decades incompatible with the natural regeneration of our planet. The most visible consequence of this ecological overshoot is climate change. Second, given the levels of multidimensional poverty and extreme poverty in Mexico, we will advocate for policies aim to improve income and wealth distributions, to the extent that pro-poor growth and green growth would increase substantially our ecological footprint over the next decades. Third, despite the available evidence, economists, and citizens in general, have some reluctance to assimilate this information. Therefore, we will outline the need to insert a representative agent that fully incorporates environmental restriction and understands that the marginal product is an economic-social-environmental fruit, and a government that is capable of design -and implement effectively- the adequate (dis)incentives to generate a sustainable economy that guarantees a minimum of material well-being for all.

\section{Neoclassical analysis of growth}

While the theory of economic growth has attracted the brightest minds in economics (a tight summary appears in Wulf, 2020), it is also true that it is currently an uneven sub-discipline in terms of quality, at least in its empirical portion. Suffice to remember the following (Durlauf, Johnson and Temple, 2005, p. 558):

"As illustrated in Appendix 2 of this chapter, approximately as many growth determinants have been proposed as there are countries for which data are available. It is hard to believe that all these determinants are central, yet the embarrassment of riches also makes it hard to identify the subset that truly matters."

Thus, following the example of the OECD (2020), which the INEGI (2013) already joined years ago, here we will use the criticized but still in force neoclassical theory of economic growth. The starting point is the aggregate production function (Solow, 1956):

$$
Q=A(t) f(K, L)
$$


Equation (1) states that the level of potential output, measured in physical units, is a function of neutral technical change (A), the capital stock (K), and the labor input (L). Solow (2005, p. 5 and p. 9) explained the analytical temporality and "calendar" of his theoretical hypothesis:

"Neoclassical growth theory is about the evolution of potential output. In other words, the model takes it for granted that aggregate output is limited on the supply side, not by shortages (or excesses) of effective demand... This suggests to me that the natural habitat of growth theoretic explanations is time-spans of 25 to perhaps 40 or 50 years. Anything much shorter is likely to mix up supply-side and demand-side effects, and anything much longer runs the risk of overlooking some events that ought to be accounted for explicitly."

Although the aggregate production function points to the determinants of long-term economic growth, namely the accumulation of capital and labor, and the introduction of technical change, it should be underlined that the critical variable, the so-called Solow residual, is not directly observable. Fortunately, in 1957 the Nobel laureate proposed the method to calculate it, that is to say, to discriminate the contributions to the economic growth of each of the arguments in the aggregate production function (Guerrero, 2009). To implement it, Solow (1957, p. 314) explained, in exemplary detail, every decision made. We want to highlight the following two:

"The capital time series is the one that will really drive a purist mad... something must be done about the fact of idle capacity... Lacking any reliable year-by-year measure of the utilization of capital I have simply reduce the Goldsmith figures by the fraction of the labor force unemployed in each year, thus assuming that labor and capital always suffer unemployment to the same percentage... The conceptually cleanest measure of aggregate output would be real net national product. But long NNP series are hard to come by, so I have used GNP instead."

The relatively abundant factor of production in the Mexican economy is labor. Thus, we will begin by presenting some stylized facts related to the capital-labor ratio and the productivity of labor. We will first address two key issues. The first, referring to the consumption of fixed capital -since in the empirical analysis we will use the net added value-, and the second, the measurement of the labor input.

Although the consumption of fixed capital at constant prices is an especially difficult variable to measure, it is acceptable, given the available information and in statistical terms, to compile it in two ways (Guerrero, 2013). It appears in the GDP account by the income method at current prices. Thus, one way to calculate it at constant prices -consistent with the compilation of the capital stockis by applying the gross fixed capital formation (GFCF) price index. Another way is by obtaining the difference of what KLEMS calls the "productive stock" and the "net capital stock", both measured at constant prices. By the accounting definitions at stake, this second way introduces an underestimation of the consumption of fixed capital. 
The following figure contains two ratios taking as a denominator the gross value added (GVA) at constant prices. The first is the consumption of fixed capital at constant prices based on the GFCF price index (Deflation), and the second is obtained as the difference of the "productive stock" and the "net capital stock" (Difference).

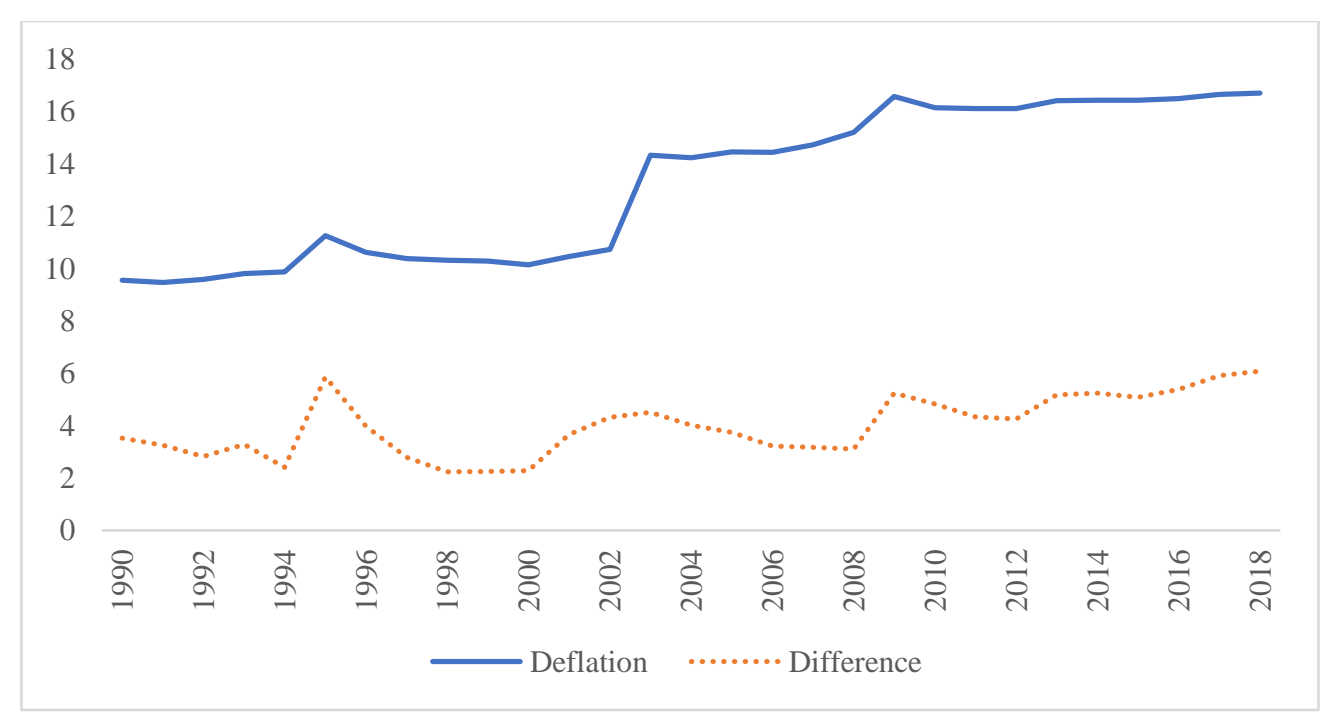

Figure 1. Ratios of consumption of fixed capital to gross value added (in percent). Source: elaboration based on INEGI.

We want to highlight first that, although the most convenient approach is based on the transformation of information from current prices to constant prices (Deflation), both proposed measurements show a similar behavior temporarily speaking. Second, the ratio obtained by deflation registered a shift of three percentage points in 2003, the first reported year of the base at 2013 prices. The above does not surprise us to the extent it occurs when agencies modify the "base year", but it will necessarily be considered when carrying out the econometric analysis.

The compilation of the GVA and the capital stock is done from different subaccounts of the System of National Accounts. Following best practices, our statistical institute uses the flow of goods method to compile the GVA and, on the other hand, the perpetual inventory method to assemble the capital stock. Likewise, following the best practices, INEGI computes the quantity of labor in an imputed way, so it correctly labels the series as the "numbers in full-time employment" ("puestos de trabajo"), and then calculates the number of hours worked. The above will also be taken into account when performing the econometric analysis. We observe the strong linear association between the number of jobs and the GVA, as expected, in the following cross-plot. 


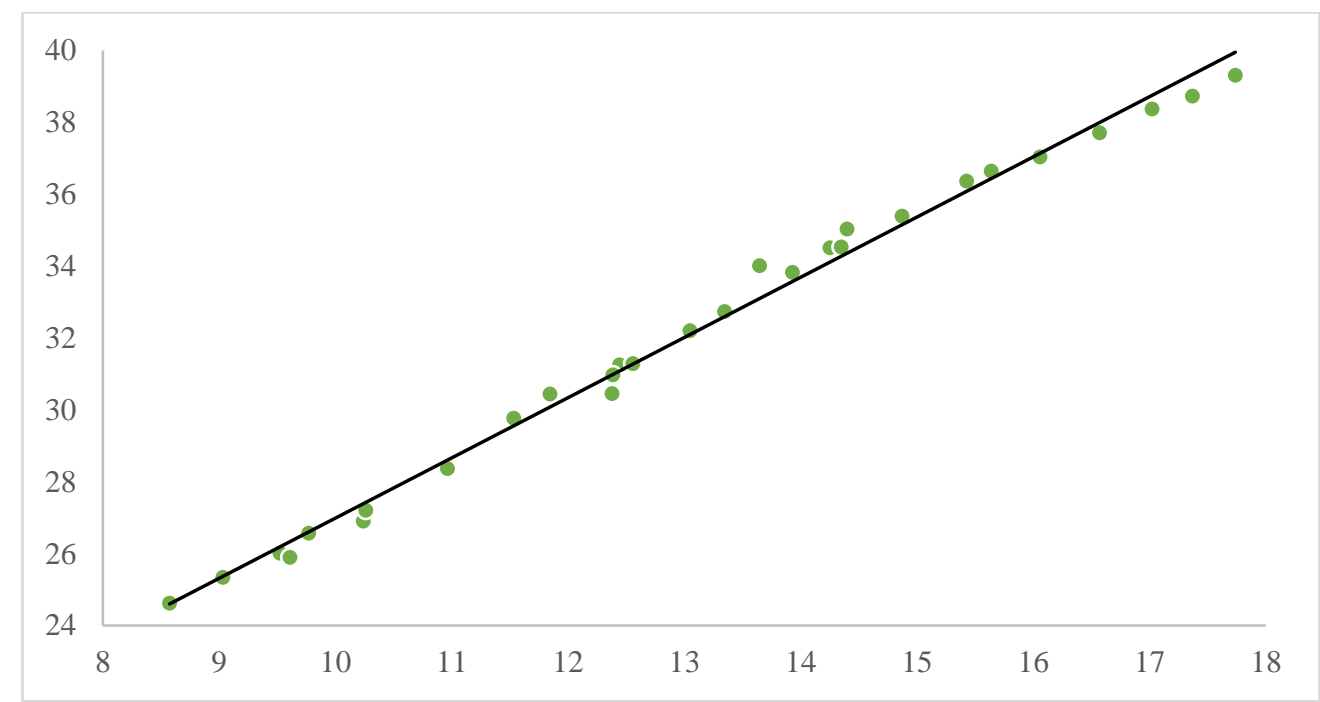

Figure 2. Cross-plot of the number of jobs and the gross value added 1990-2018 (in millions of people and trillions of pesos at 2013 prices).

Source: elaboration based on INEGI.

The capital-labor ratio denotes a technical coefficient measured in quantities, so it is expected, first, that it does not vary significantly in the short term. Second, that it registers shifts as a consequence of supply shocks -those originated basically but not exclusively in the technical change, for example a lockdown-, and third, that it reflects the permanent process of (de/re)valuation of the capital stock. In the same direction, recognizing that the level of employment behaves pro-cyclically, this ratio will also reflect the ups and downs of the business cycle. In accounting terms, the observed value that best expresses it is the ratio between the net capital stock and the number of jobs.

The empirical capital-labor ratio can be calculated using the information contained in KLEMS (INEGI, 2013). But doing so would imply assuming full employment. We may use surveys at hand to improve it (the Quarterly on Business Economic Activity TAEE, the Monthly Industrial Activity IM, the Monthly on Manufacturing Industry EMIM, and the Monthly Business Opinion Survey MOE). The following figure contains the capacity utilization of the fixed capital according to the mentioned different statistical exercises. 


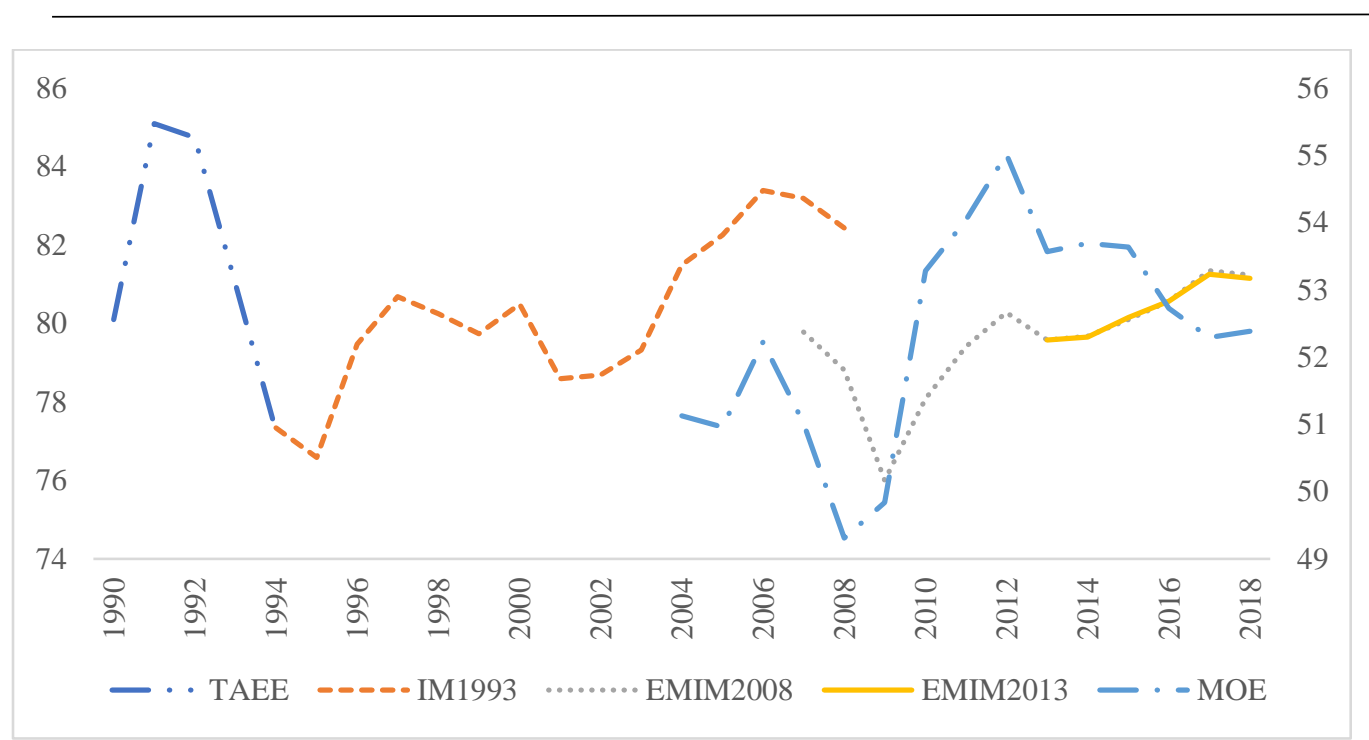

Figure 3. Capacity utilization in manufacturing 1990-2018 (in percent, on the left axis TAEE, IM, and EMIM, on the right MOE).

Source: elaboration based on INEGI.

Leaving aside the Monthly Business Opinion Survey (MOE), between 1990 and 2018, the percentage of capacity utilization was 78.9 on average, with a minimum of 74.5 and a maximum of 82.7 (annual figures). In the following table, we display two versions of the empirical capital-labor ratio in manufacturing, one based on the stock of net capital registered in KLEMS as the numerator, and the other adjusted by its capacity utilization.

Table 1. Capital-labor ratio in the economy, in the tertiary sector, and manufacturing (observed and adjusted), in millions of pesos at the 2013 prices per labor unit, 1990-2018.

\begin{tabular}{|c|c|c|c|c|}
\hline & Economy & $\begin{array}{c}\text { Tertiary } \\
\text { sector }\end{array}$ & Manufacturing & $\begin{array}{c}\text { Manufacturing } \\
\text { adjusted }\end{array}$ \\
\hline 1990 & 0.826 & 2.685 & 0.159 & 0.124 \\
\hline 1991 & 0.830 & 2.744 & 0.156 & 0.129 \\
\hline 1992 & 0.839 & 2.825 & 0.158 & 0.130 \\
\hline 1993 & 0.850 & 2.982 & 0.160 & 0.126 \\
\hline 1994 & 0.875 & 3.194 & 0.163 & 0.122 \\
\hline 1995 & 0.918 & 3.460 & 0.161 & 0.120 \\
\hline 1996 & 0.894 & 3.352 & 0.162 & 0.125 \\
\hline 1997 & 0.885 & 3.223 & 0.165 & 0.129 \\
\hline 1998 & 0.874 & 3.177 & 0.170 & 0.133 \\
\hline 1999 & 0.888 & 3.228 & 0.179 & 0.138 \\
\hline 2000 & 0.899 & 3.257 & 0.184 & 0.144 \\
\hline 2001 & 0.932 & 3.521 & 0.188 & 0.144 \\
\hline 2002 & 0.970 & 3.865 & 0.191 & 0.146 \\
\hline 2003 & 0.965 & 3.558 & 0.193 & 0.149 \\
\hline 2004 & 0.961 & 3.647 & 0.193 & 0.153 \\
\hline
\end{tabular}




\begin{tabular}{|l|l|l|l|l|}
2005 & 0.973 & 3.744 & 0.192 & 0.154 \\
\hline 2006 & 0.973 & 3.855 & 0.191 & 0.154 \\
\hline 2007 & 0.987 & 4.073 & 0.192 & 0.155 \\
\hline 2008 & 1.009 & 4.276 & 0.197 & 0.158 \\
\hline 2009 & 1.062 & 4.760 & 0.195 & 0.148 \\
\hline 2010 & 1.072 & 4.815 & 0.196 & 0.153 \\
\hline 2011 & 1.076 & 4.879 & 0.197 & 0.156 \\
\hline 2012 & 1.078 & 4.901 & 0.198 & 0.159 \\
\hline 2013 & 1.095 & 4.688 & 0.206 & 0.164 \\
\hline 2014 & 1.109 & 4.758 & 0.215 & 0.172 \\
\hline 2015 & 1.117 & 4.676 & 0.225 & 0.180 \\
\hline 2016 & 1.123 & 4.735 & 0.228 & 0.184 \\
\hline 2017 & 1.134 & 4.706 & 0.232 & 0.189 \\
\hline 2018 & 1.137 & 4.689 & 0.235 & 0.191 \\
\hline
\end{tabular}

From the previous table, we emphasize, first, that the intensity of capital is different in the economy as a whole and the manufacturing, both due to the role played by the tertiary sector and the productive heterogeneity of manufacturing economic units; and second, that the four technical coefficients display an upward trend.

Another critical ratio is the output per man. Its behavior reflects, among other economic phenomena, the individual productive effort of workers, the availability of capital, that is, the capitallabor ratio, and the business cycle.

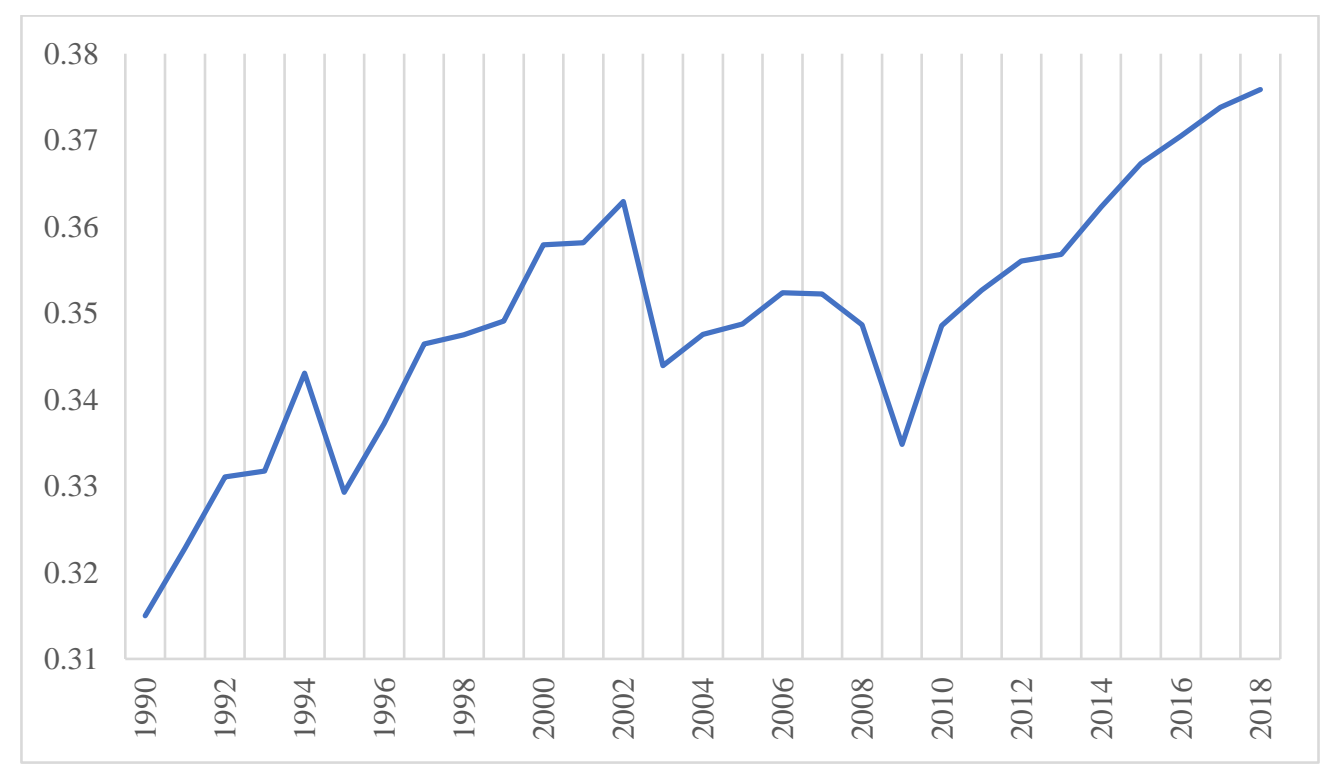

Figure 4. Labor productivity 1990-2018 (millions of pesos at 2013 prices per man). Source: elaboration based on INEGI. 
We highlight three facts: A lower level of labor productivity in 2003 -which is an accounting phenomenon derived from the increase in consumption of fixed capital in 2003-, a fall in 2009 that does not reflect a technical phenomenon but the contraction of the economy linked to the great crisis and the pandemic linked to AH1N1 and, seen the whole available analyzed period, an upward trend. These stylized facts serve to remind us that labor productivity evolves pro-cyclical and, consequently, is influenced by the public policies, both supply and demand-side policies.

The aggregate production function is nonlinear. To approach it from the econometric analysis, that is, from the classic linear regression model (CLRM), we need to calculate the natural logarithms of the variables in play. Thus, the instrument for measuring elasticities and technical change -the one-equation statistical model- corresponds to the mathematical model proposed in equation (1).

From KLEMS, we obtained the following data. First, the net value added -equals to GVA minus the consumption of fixed capital using the deflation method; second, the stock of net capital, of the economy as a whole and manufactures -which we adjusted according to the capacity utilization(KManCU); and third, the number of jobs (L) disaggregated by sectors, primary, secondary (Sec), manufacturing (Man), and tertiary, and their equivalent in terms of worked hours (Hrs).

The one-equation model contained in (2) shows the results of the estimation of the aggregated production function by ordinary least squares for the period 1990-2018. By the way, all the empirical work carried out throughout the document used the complete set of available information generated by INEGI in terms of its extension and frequency. We included a dummy variable with zeros between 1990 and 2002, and ones between 2003 and 2018, to capture the accounting effect of the base year change.

$$
\begin{aligned}
\log (\mathrm{NVA})= & (-0.002)+0.320^{*} \log (\mathrm{KManCU})+0.656 * \log (\text { HrsMan })+(-0.042) * \text { Dummy } \\
& (-0.01)
\end{aligned}
$$

In the statistical annex we show the results of some tests carried out to verify the statistical adequacy of the regression, the non-stationarity of the included variables, and as a mechanism to avoid the spurious regression critique, the stationarity of the residuals (Engle and Granger, 1987; Hendry, 2000; Spanos, 2003). In general, the test results were acceptable. The constant represents the Solow residual -the so-called total factor productivity (TFP)- and, if we calculate its exponent, we obtain a positive number in millions of pesos at 2013 prices. Its statistical significance measured by the $t$ value was rejected, a fact that does not surprise us given the performance of the Mexican economy during the analyzed period. The other two estimated coefficients make sense in terms of their value and sign; they were statistically significant and should be interpreted as elasticities. The hours worked in the primary and tertiary sectors were not significant. The determination coefficient was 0.98 , which is not a surprise either since behind the proposed specification, we have an identity 
equation. ${ }^{2}$ The following figure contains the actual values, the fitted values, and the errors of the estimated regression.

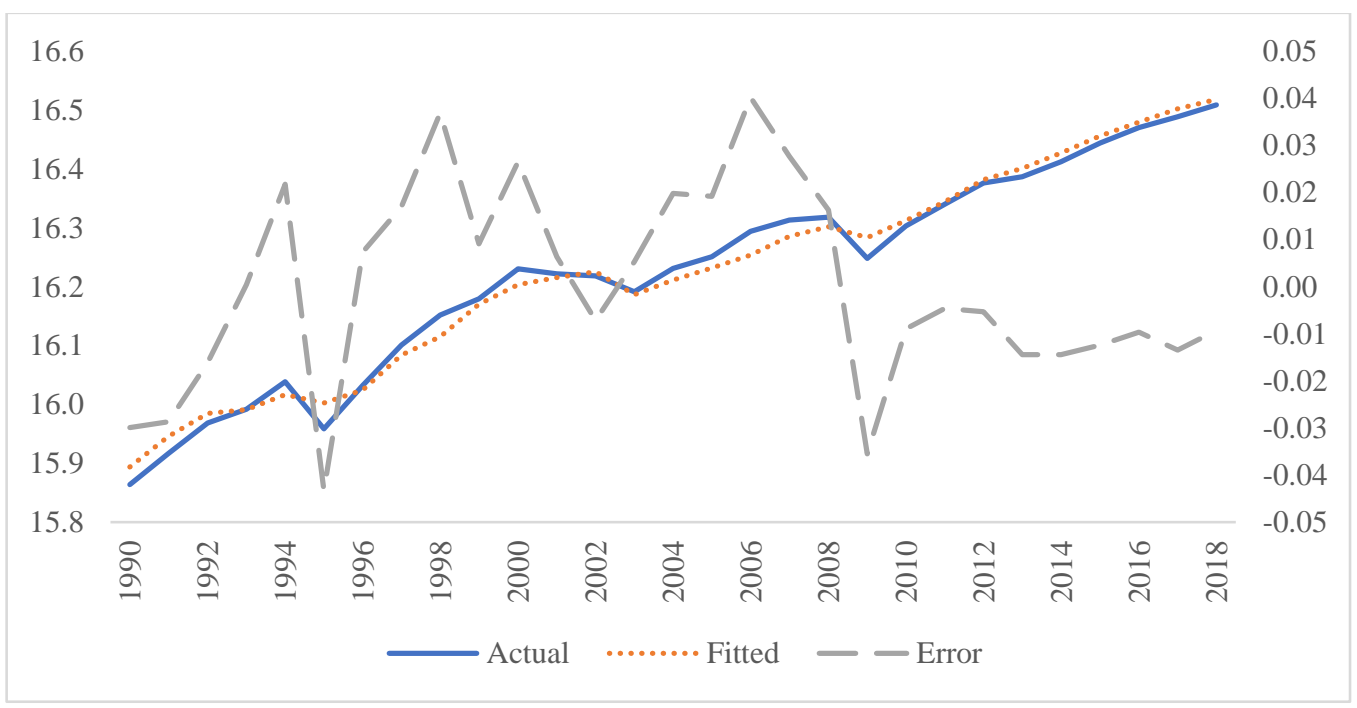

Figure 5. Actual, fitted, and error values (in logs; actual and fitted right axis, left errors)

We highlight that the model overestimates in 1995, 2009, and after the great recession, which indicates the existence of idle productive capacities in the Mexican economy. In the same direction, we carried out another regression analysis substituting the number of hours worked for the numbers of employment. The results were similar in all respects, the technical change was not significant, and only the numbers of full-time jobs in the manufacturing sector registered a t value greater than two.

The next step to carry out our simulations was to conduct an econometric analysis taking as an endogenous variable the number of worked hours in the manufacturing sector. According to the aggregate production function, its determinant is, firstly, the stock of capital in use and, secondly, drawing on an economic-statistical sense, its lagging value. The estimation results were as follows:

$$
\operatorname{HrsMan}=2,059,915+1.31 * \mathrm{KManCU}+0.83 * \operatorname{HrsMan}(-1)
$$

Once again, in the annex, we show the results of some tests carried out to verify the statistical adequacy of the regression, and as a mechanism to avoid the spurious regression critique, the stationarity of the residuals. Both the constant and the two variables were statistically significant, and the determination coefficient was 0.99. In this case, the estimated parameters should be understood as marginal propensities. This second equation is necessary to be able to simulate the values of some variables in the post-sample period 2020-2024, as we will discover later.

\footnotetext{
2 In the same direction, in the five regressions reported by Solow (1957, p. 319) the coefficients of determination was 0.99. To the extent that he used the labor productivity as the dependent variable and the adjusted capital-labor ratio as the independent, it was generated a problem of endogeneity (an Haavelmo bias).
} 
We carried out a first simulation exercise. Using the estimated production function, we set another percentage in the degree of capacity utilization -adding to the rate of use registered in each year five percentage points. Thus, for example, the maximum historical rate of 82.7 observed in 1991 was now 87.7, and so for every available observation. We then simulate another trajectory of the Mexican economy during the analyzed historical period:

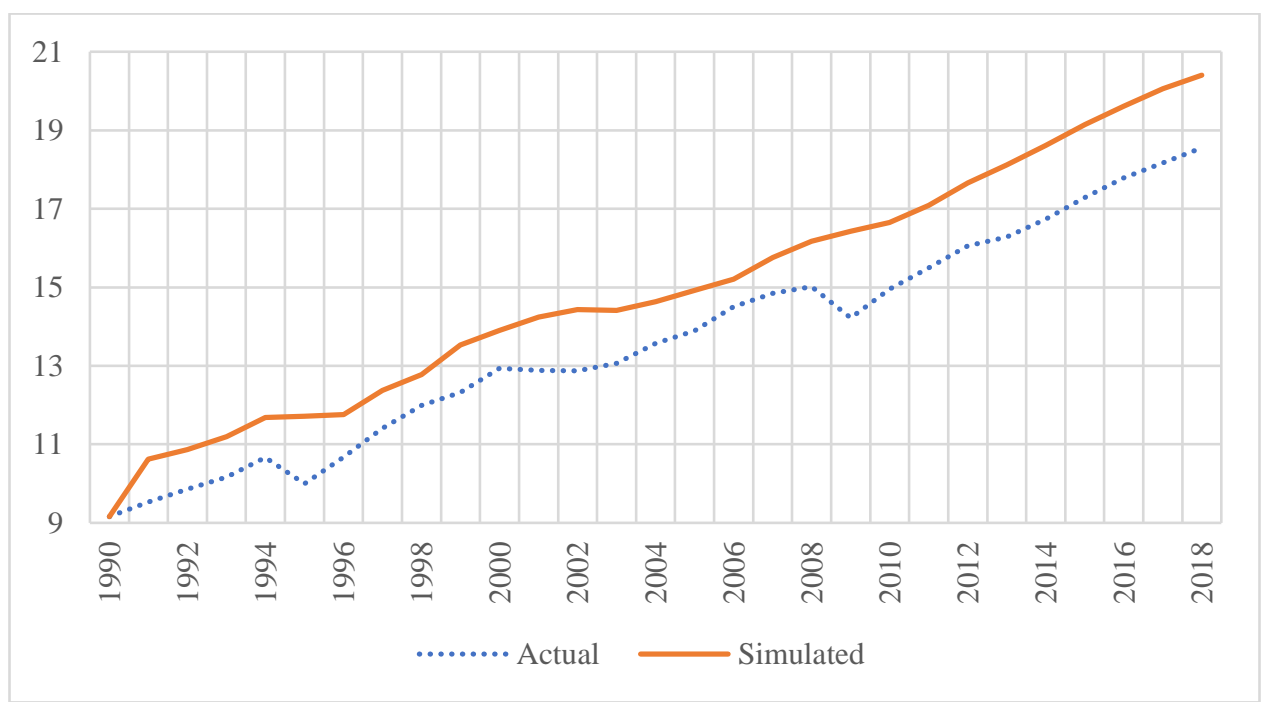

Figure 6. GDP in volume, actual and simulated 1990-2018 (trillions of pesos at 2013 prices). Source: elaboration based on INEGI.

Between 1990 and 2018, the average annual growth rate of GDP was 2.55 percent. The results of our simulation gave a rate of 2.90 percent. We want to highlight two considerations. Although we set a degree of utilization of the capital stock that would imply a state of productive "heating", the growth of GDP in volume obtained by simulation was only slightly higher, that is, it did not even jump a percentage point. On the other hand, the proposed simulation contrast with the poor performance of the Mexican economy in 1995 and 2009 in the sense that its trajectory was sustained upward; and also in 2010, considering its level observed in 2008. Thus, in counterfactual terms, a question arises on the role that unconventional active economic policies can play in the face of an adverse scenario, such as the current lockdown, followed by shocks of internal and external demand.

Our second simulation has two parts. The first is linked to the scenario proposed by the Criterios Generales de Política Económica 2021. The document recently published by SHCP established as goals of economic growth for 2020, 2021, 2022, 2023, and 2024 the following values, respectively: $-8.0,4.6,2.6,2.5$, and 2.5 percent, implying an average annual growth rate of 0.74 percent between 2019 and 2024. Based on our econometric results, we determine the requirements in terms of the change of the capital stock in use. The second part of the simulation is linked to a four percent growth of the economy in the same period. The results were the following. 


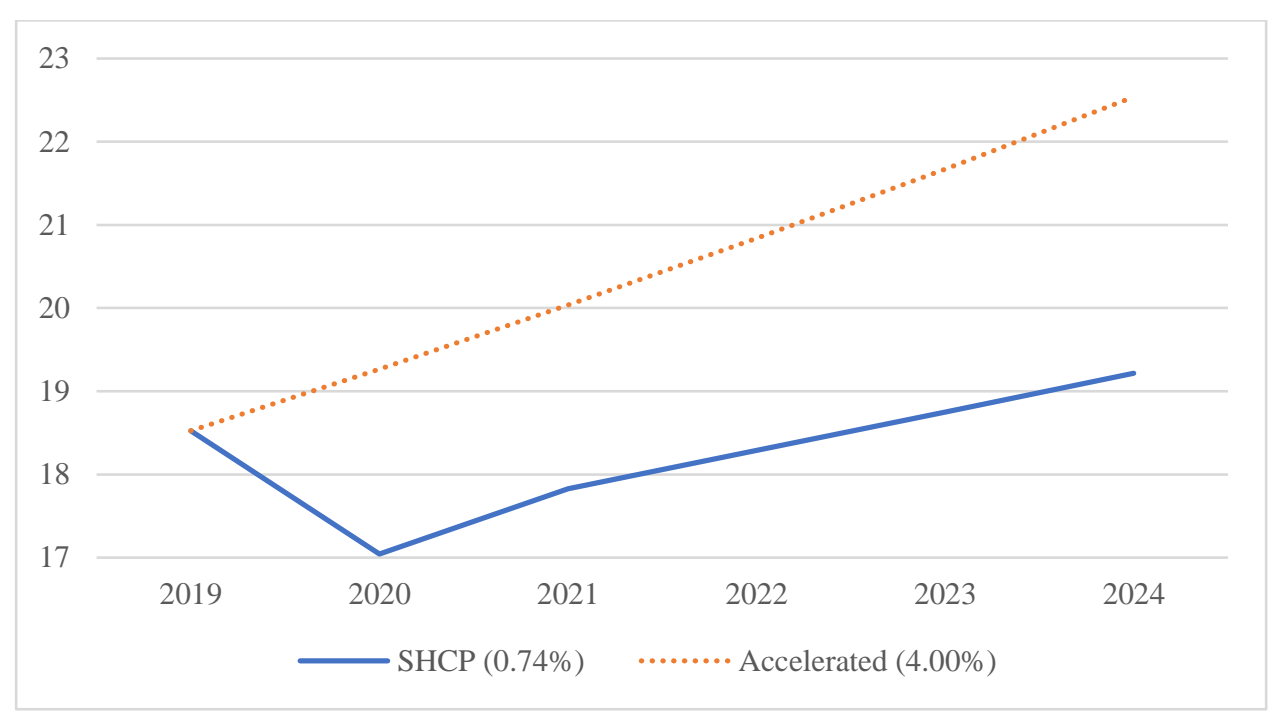

Figure 7. GDP in volume, according to SHCP, and our proposal for "accelerated" growth 20192024 (trillions of pesos at 2013 prices).

Source: elaboration based on INEGI.

To evolve according to the goals proposed by SHCP, the stock of capital in use should change an annual average of two percent in the period 2019-2024. For the Mexican economy to achieve accelerated growth, the stock of capital in use should change, on average, ten percent. And the question is immediate: how possible is it to accumulate the necessary capital requirements, and their effective use, for the economy to grow at 0.74 percent and 4.00 percent? The answer, from a historical perspective, appears in the following figure.

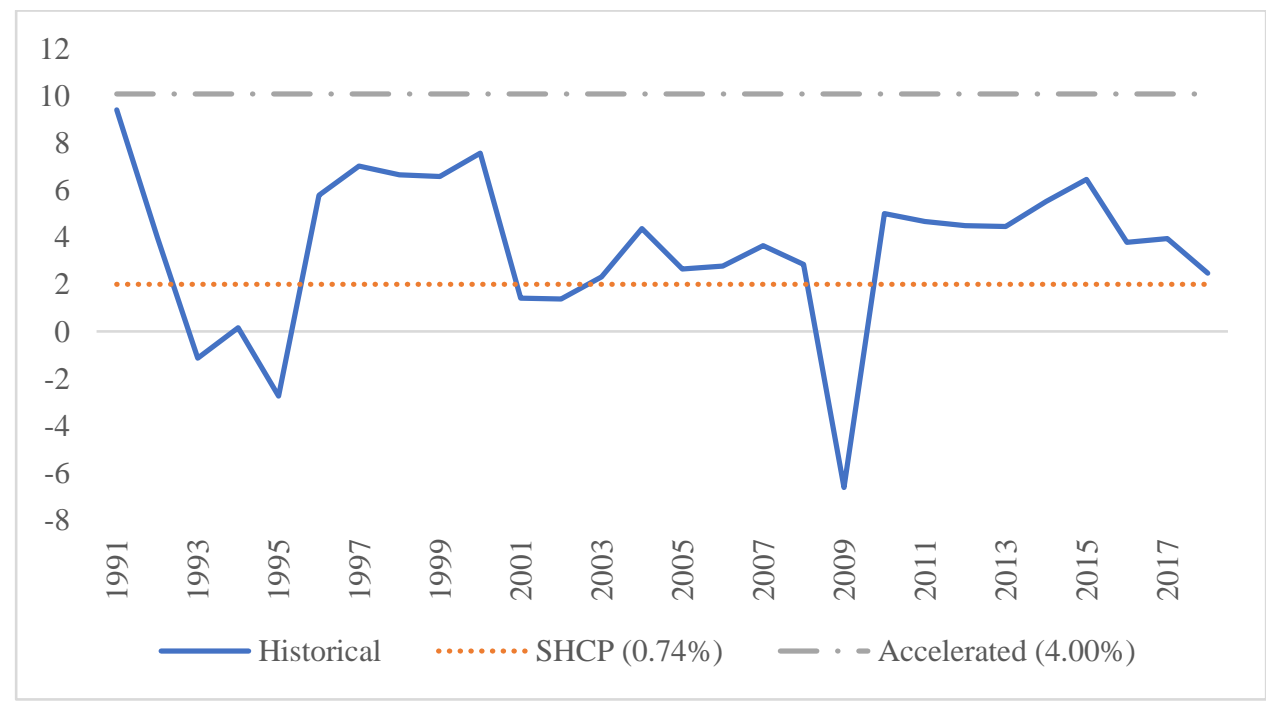

Figure 8. Change of the capital in use in manufacturing, historical, and that required according to the goals of the SHCP and a scenario of accelerated economic growth (in percent). Source: elaboration based on INEGI. 
Thus, historically speaking and considering the current circumstances, the dynamic of capital in use necessary to reach the goal of the administration seems possible. And the recipe is at hand: according to the first simulation shown above, a key to economic recovery is the increase in the stock of capital in use. We emphasize that this will not happen spontaneously but as a result of the application of unconventional active economic policies, that is, policies to expand aggregate demand effectively.

\section{Post-Keynesian analysis of growth}

The literature also recognizes that an economy faces an external restriction to growth on the demand side. Currently, it is available its third-generation version known as "Thirlwall's law with an emphasis on the ratio of exports/imports income elasticities" (Guerrero, 2006). This other restriction is reasonable if we remember the percentage of idle capital, according to the surveys mentioned in the previous section. Thirlwall's model can be represented by three equations:

$$
\begin{aligned}
& x=\eta\left(p_{d}-p_{f}\right)+\pi w \\
& m=\phi\left(p_{f}-p_{d}\right)+\xi y \\
& \left(p_{d}+x\right)=\left(p_{f}+m\right)
\end{aligned}
$$

With $\eta, \phi<0$ and $\pi, \xi>0$. Here, $\mathrm{x}, \mathrm{m}, \mathrm{w}$, and $\mathrm{y}$ are the growth rates in volume of exports, imports, rest of the world income, and domestic income respectively, and $\left(p_{d}-p_{f}\right)$ is the growth rate of relative prices measured in a common currency. Equations (4) and (5) are standard export and import demand functions. Price elasticities of exports and imports are $\eta$ and $\phi$ respectively. Income elasticities of exports and imports are $\pi$ and $\xi$ respectively. It is worthwhile to highlight that both income elasticities reflect the non-price aspects of competition (McCombie and Thirlwall, 1994, p. 265, Bairam and Dempster, 1991, p. 1720). Equation (6) assumes that the current account is continuously balanced.

Substituting equations (4) and (5) into (6) gives the balance of payments constrained growth model rate of real domestic income, designated by $y_{b}$ :

$$
y_{b}=\frac{\pi w+(\eta+\phi+1)\left(p_{d}-p_{f}\right)}{\xi}
$$

As Thirlwall points out (1979, p. 49), if the assumption can be made that the Marshall-Lerner condition is exactly satisfied or if relative prices measured in a common currency do not change over the long run, equation 7 can be reduced to:

$$
y_{b}=\frac{\pi w}{\xi}
$$


About equation (5), Davidson (1990-91, p. 300) clarifies: "the rate of growth a nation can maintain without running into a ceteris paribus balance of payments problem depends on the rest of the world's real economic growth and the relevant income elasticities for imports and exports." And its policy implications are relevant in the sense that, in an open economy, appropriate economic management is the one that manipulates the income elasticities of exports and imports (Bairam and Dempster, 1991, p. 1720): "A successful economic policy that increases the value of $\pi$ and/or reduces the value of $\xi$, relaxes the balance of payments constraints and, eventually, accelerates economic growth."

Allowing a stochastic residual term $\left(u_{t}\right)$, equation (8) can be written as:

$$
y_{b, t}=\alpha w_{t}+u_{t}
$$

Here $\alpha=\frac{\pi}{\xi}$ is the coefficient. It is expected to be positive -and the larger it is, the better. Its vector autoregressive (VAR) form is the following:

$$
\begin{gathered}
y_{M X, t}=\alpha_{0}+\alpha_{i} y_{U S, t-i}+\alpha_{i} y_{M X, t-i}+u_{M X, t} \\
y_{U S, t}=\beta_{0}+\beta_{i} y_{U S, t-i}+\beta_{i} y_{M X, t-i}+u_{U S, t}
\end{gathered}
$$

Where $y$ is the natural logarithm of the real gross domestic product, i indicates the number of lags required, and $u_{t}$ are iid $N(0, \Omega)$ processes.

The following figure contains the levels of manufacturing GDP of the United States and GDP in Mexico in volume. It seems that both variables share a common time-path.

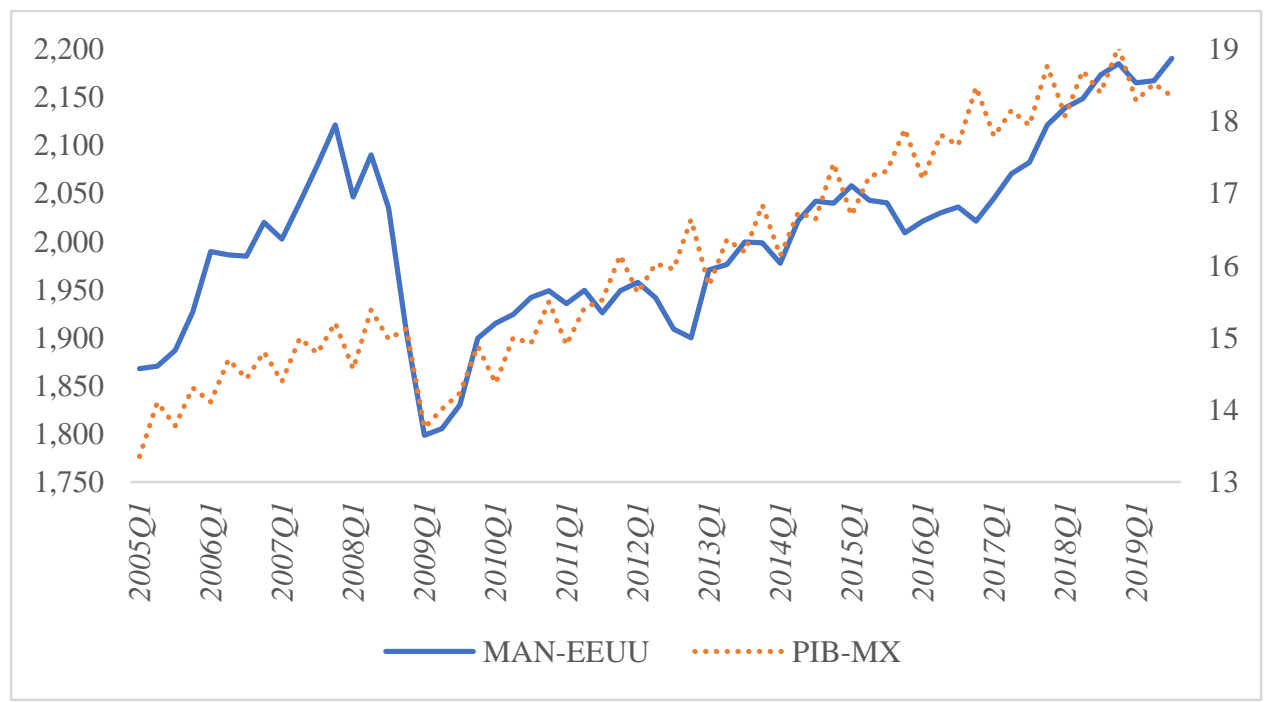

Figure 9. Manufacturing GDP of the United States and GDP of Mexico (billions of dollars chained in 2012 left axis, and trillions of pesos at 2013 prices right axis)

Source: elaboration based on BEA and INEGI. 
We estimate a VAR model with four lags under a double logarithmic functional form between 2015Q1 and 2019Q3. In the statistical annex, we show the results of some tests carried out to gain confidence in its use as a measuring instrument (Boumans, 2007, p. 3). In short, the test results were acceptable. The Johansen test in its two versions showed the existence of a cointegration vector reporting a value of 2.17325, that is, for each percentage point of growth in the American manufacturing GDP, the change of the Mexican GDP amounts to 2.17 percent.

Based on our econometric results, we can state that the growth goal for the next years set by SHCP, namely 0.74 percent, would require a change in US manufacturing production of 0.35 percent. In the case of accelerated growth, that is 4 percent, it would require a change of 1.84 percent. The obvious question is whether, in the coming years, manufacturing production in the United States will perform well or poorly. Drawing on recent history, we note that between 2006 and 2018 (the analyzed period), and 2010 and 2018 (the post-crisis sub-period), manufacturing GDP grew by an annual average of 0.67 percent and 1.41 percent respectively. In this sense, in the first situation, the Mexican economy could grow without deteriorating its current account approximately 1.45 percent, and in the second 3.06 percent. On the other hand, the growth in the manufacturing production index was -7.57 and -7.04 percent in July and August of 2020. Thus, we are not optimistic about the economic performance of either country in the next years.

\section{Biocapacity constraint on growth}

Environmental literature criticizes the catastrophic modern myth of perpetual economic growth. And we agree, the theories of economic growth are such, of economic growth. The first truly restriction is that linked to nature -to the biocapacity of our planet. We should review some definitions before carrying out the empirical exercise.

Biocapacity is the biological power of our planet to regenerate and reproduce plant matter. This primary productivity of nature is the source of all life, including human life. Biocapacity is not an invention in the same way that gravity is not. Both are forces of nature that we can observe and measure (Wackernagel, Beyers, and Rout, 2019).

Another clue definition is the ecological footprint, which simply accounts for our use of biocapacity and waste management, all of the above given the technologies used. While for the market economy, money is typically used as the accounting unit, the footprint uses biologically productive surfaces of the earth as its currency -the global hectare. These surfaces harbor the most significant resource on our planet: the capacity of the earth to renew itself.

To assess biocapacity, ecological footprint, and their difference (called excess or deficit), the Global Footprint Network tracks each country using up to 15,000 data per year contained in the bases built within the United Nations (UN). Depending on the quality and availability of the information, as is the case with other global databases -for example those linked to surveys applied to families to measure the distribution of income and wealth-, the organization provides a rating to it.

Incidentally, the accounting used is admittedly cautious. For example, an error is accepted by underreporting since not all demands for goods and services, and their ecological footprint, are counted -simply because not all spending is reflected in UN statistics. In the same direction, biocapacity will most likely be overestimated as some harmful activities, such as soil erosion or 
groundwater loss, are still not taken into account due to the lack of complete and consistent data. Therefore, biocapacity deficits are likely to be greater than what the Footprint Network reports for the world and Mexico.

The footprint reveals how much of the productive area of our planet is used for each human activity. According to the most recent calculations made by the Footprint Network, humanity overused nature's biological budget -the planet's biocapacity- by $75 \%$ in 2016 . In other words, humanity currently uses nature $75 \%$ faster than what is renewed. This overuse is called ecological overshoot.

The following figure displays the GDP in volume and the ecological footprint for Mexico, actual data of GDP between 1960 and 2019, and of the ecological footprint between 1960 and 2016. To forecast their levels until 2034 -a selected year to be explained later-, we use the average annual GDP change between 2008 and 2018, namely 2.14 percent, a figure quite similar to the potential growth estimated by SHCP (2018). We estimate a VAR model between the pair of variables between 1960 and 2016 under a double logarithmic functional form. In the annex, we show its statistical test results. According to the Johansen test, in its rank and trace versions, there is a cointegration vector whose only parameter amounted to 1.17 percent. $^{3}$ The following graph contains the levels of both variables.

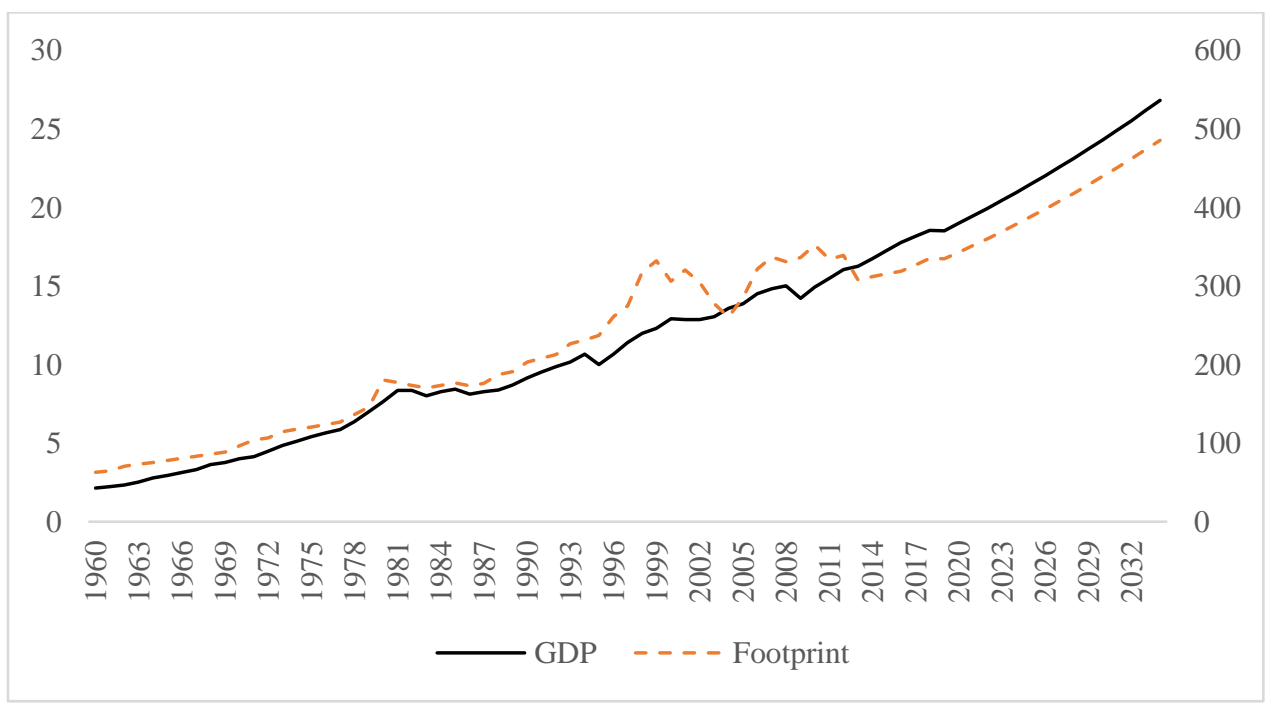

Figure 10. Mexico's GDP and its ecological footprint 1960-2034 (in billions of pesos at 2013 prices left axis, and in millions of global hectares right axis) Source: elaboration based on CONAPO, INEGI, and the Global Footprint Network.

${ }^{3}$ Using a quantile autoregressive lagged approach, Sharif, Baris-Tuzemen, Uzuner, Ozturk, and Sinha (2020) also found a cointegration relationship between the ecological footprint and the GDP for the case of Turkey. One of their conclusions was the following (p. 10): "In particular, the outcomes suggested that renewable energy decrease ecological footprint in long-term on each quantile. However, the results of economic growth and non-renewable energy impact positively to ecological footprint at lower quantiles to upper quantiles. This implies that in long-term, economies at different level of growth carry greater damage to the environment." To understand some of its implications in terms of the Kuznets curve see Valencia-Herrera, Santillán-Salagado, and Venegas-Martínez (2020). A relatively similar story can be told from an energy consumption perspective (see for example Lagunas, Oropeza and Boggio, 2020). 
The difference between biocapacity and ecological footprint is known as surplus or deficit. The following figure shows it with an inverted sign. We smoothed it using the Hodrick-Prescott filter. Our general purpose is to show how, in the long run, we moved from a surplus situation between the 1960s and the mid-1970s to an increasing deficit situation since then. Incidentally, the entire world consumes more natural resources than the earth has regenerated since 1970. And we all know one of its collateral -the climate change.

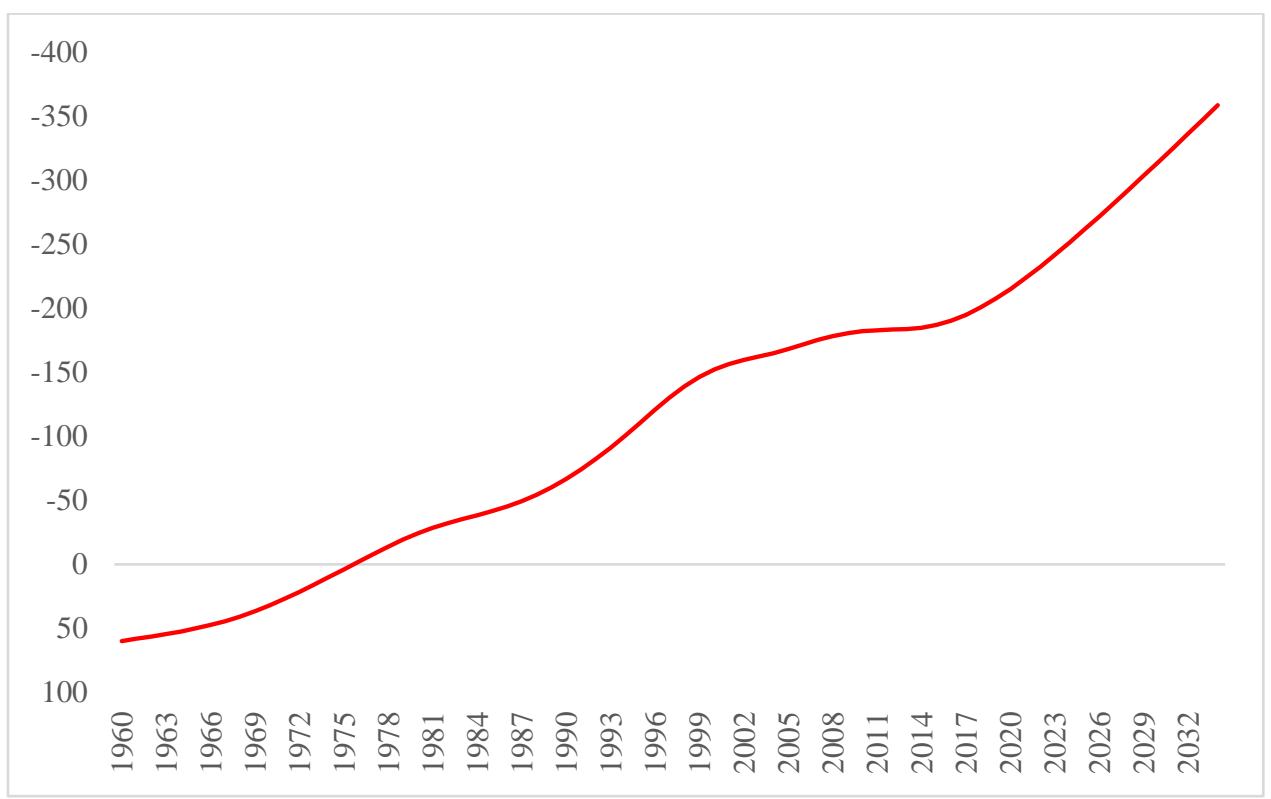

Figure 11. Surplus and deficit in Mexico 1960-2034 (in millions of global hectares, inverted scale)

Source: elaboration based on CONAPO, INEGI, and the Global Footprint Network.

The economic-environmental scenario is unsustainable. In the same direction, the Footprint Network points out that if the entire world population were to receive the per capita income observed in Mexico in 2016 (9,868 dollars at 2010 prices), it would require a planet 1.59 times bigger. Or what is equivalent, the size of Mexico would have to multiply by 2.21 to equals the biocapacity and the footprint, taking that income per person as a reference.

Although Mexico is part of the group of countries with middle incomes, poverty statistics are still terribly disappointing. Due to methodological issues and the availability of information, we only have data on multidimensional poverty and extreme poverty from 2008 to 2018 with a biannual frequency. Between those years, the percentage of the population in poverty decreased from 44.83 to 41.83 , and in extreme poverty from 11.17 to 7.43 . A deterministic trend yielded an acceptable adjustment to simulate both variables. The figure shows that we would reduce poverty to zero until 2034 and 2148 -assuming a scenario similar to that observed between 2008 and 2018. 


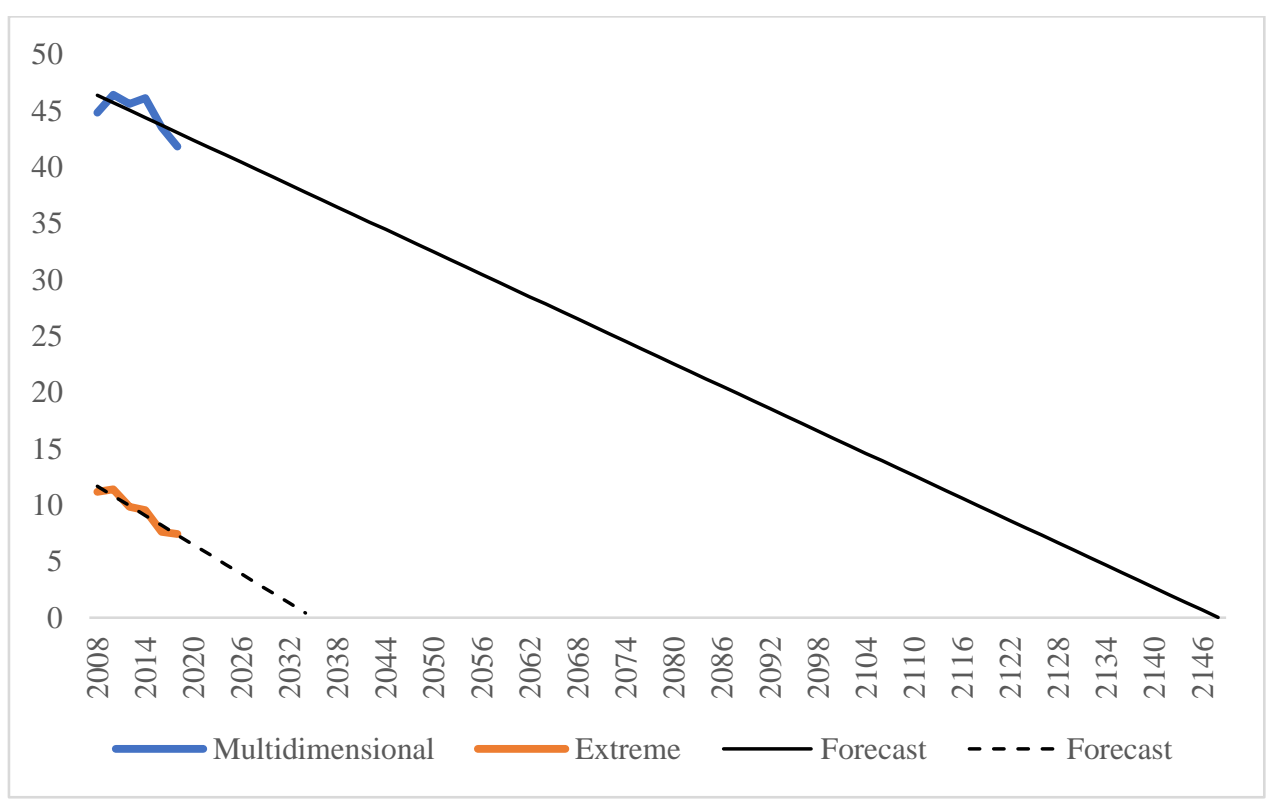

Figure 12. Percentage of the population in multidimensional poverty and extreme poverty Source: elaboration based on CONAPO, CONEVAL, INEGI, and the Global Footprint Network.

The results cast a bleak future. Under the proposed economic growth scenario $(2.14 \%$ annual average) and considering the same effectiveness of anti-poverty policies -ceteris paribus-, the ecological footprint will increase substantially, and it will take many years to eradicate it in Mexico. Our common sense tells us that we have and must radically change our perspective on how to build a country in which all Mexicans live with dignity - under sustainable economic functioning.

\section{Conclusions}

It is out of the question that the first constraint to economic growth is the biocapacity of the planet. Considering that the ecological footprint has exceeded biocapacity for half a century, we must all stop thinking exclusively in terms of economic growth. Nowadays, the great challenge is to make any economic-social result compatible with a planet. Thus, the fight against poverty does not go through the promotion of growth, at best pro-poor, but through the distribution of income and wealth, to guarantee minimum material well-being for any citizen. The current state of crisis does not go through its economic definition linked to the temporary fall in production. Still, it is connected to the destruction of the biocapacity with a permanent character. All the above should lead us to do everything necessary to improve the techniques of production and waste management. We have before us the possibility of creating a better civilization.

Even though there is sufficient information about the growing gap between biocapacity and the ecological footprint -and that one of its devastating effects, climate change, is visible for all of us-, we found some resistance to its acceptance among citizens in general and the community of economists in particular. The former simply ignore it, and the latter minimizes it, arguing, for example, the quality of the measurements. 
In this regard, we point out that any statistical measurement is subject to errors and biases, and the Footprint Network has included them in its work schedule. Also, it is relevant that statistical institutes establish a commitment to collect all the necessary information, in quantity and quality, to measure our biocapacity and footprint, by country and planetary. In this way, the environmental issue would be visible to all and would occupy the first place on the public agenda.

It is pertinent to address the statistical quality of the System of National Accounts (SNA) and its emblematic variable, the GDP. In a book recently published by the OECD (Lequiller and Blades, 2014, p. 44), we read the following:

"National accounts could better be called 'national accounts statistics' because without this qualifier users may think they are as reliable as the business accounts of a company. This is not true. In particular, while GDP for technical reasons is often expressed in millions of units of the National currency, users should be aware that they are very, very far from being accurate at the level of millions. National accounts' quality is highly dependent on the quality of the statistical system that exists in a given country. And in all countries, at varying degrees, this system does not cover all units, leaving a significant number of adjustments to be made. National accounts data are therefore approximations. It is not even possible to give a summary figure of the accuracy of the GDP. Indeed, national accounts, and in particular GDP, are not the result of a single big survey for which one might compile a confidence interval. They are the result of combining a complex mix of data from many sources, many of which require adjustment to put them into a national accounts database and which are further adjusted to improve coherence, often using non-scientific methods."

Given the formidable statistical challenge and the lack of information, the compilation of the variables contained in the SNA involves the application of non-scientific methods. In the same direction, how big are the errors and biases into the SNA? A recent benchmark is Moulton (2018), who worked for 32 years in the US statistical system. Moulton (p. 31 and p. 33) estimated an upward bias in the inflation rate of 0.85 percentage points per year and a downward bias in the economic growth of around 0.65 percentage points per year in the years after the Boskin Commission. According to the Bureau of Labor Statistics (BLS) and Economic Analysis (BEA), the average annual inflation rate was $2.14 \%$ between 1997 and 2017, and the economic growth was $2.27 \%$ in the same period. Incidentally, underestimation of economic growth and ecological footprint go hand in hand.

Economic theories have not fully incorporated the sustainability criterion. Pollution is hardly addressed as a market failure, and policy instruments are spoken of as the mechanism to attack it -for example, the valuation of nature using hedonic techniques. In the same direction, the OECD has already initiated a green growth project.

Our view is that sustainability has to be incorporated across the length and breadth of economic science. We cannot continue: 1) To define economics as the science of choice without making explicit the biocapacity of the planet; 2) To use an atomized rational agent -instructed to maximize only her (individual) utility under any circumstances-, and 3) To teach that the appropriation of income is due to "individual effort". We need the insertion of an agent who fully recognizes her ecological footprint and acknowledges that her marginal product is an economic- 
social-environmental fruit, and of a government capable of designing and implementing the adequate (dis)incentives to generate a sustainable economy in the immediate future. Economic science has to provide creative solutions to a problem that compromised human existence currently.

\section{References}

[1] Boumans, M. (2007), "Introduction", pp. 3-18, Marcel Boumans (editor), Measurement in Economics: A Handbook, Amsterdam, Academic Press.

[2] Bureau of Economic Analysis (2020), "Technical note: Gross Domestic Product, first quarter of 2020 (advance estimate)", open-access.

[3] Desai, P. and King, P. (2006), One Planet Living, Alastair Sawday Publishing.

[4] Durlauf, S. N., Johnson, P. A., and Temple, J. R. W. (2005), “Growth econometrics”, pp. 555-677, Philippe Aghion and Steven Durlauf (editors), Handbook of Economic Growth, Vol. 1A, Elsevier.

[5] Engel, R. and Granger, C. (1987), "Co-integration and error correction: representation, estimation, and testing”, Econometrica, 55(2), pp. 251-76. (10.2307/1913236)

[6] Guerrero, C. (2006), "Thirlwall's law with an emphasis on the ratio of exports/imports income elasticities in Latin American economies during the Twentieth Century", Estudios Económicos, 21(1), pp. 23-44. (https://doi.org/10.24201/ee.v21i1.159)

[7] Guerrero, C. (2009), "Contribution of the information and communication technology sector to Mexican Economic growth from 1999 to 2003", EconoQuantum, 6(1), pp. 11-30. (https://doi.org/10.18381/eq.v6i1.96)

[8] Guerrero, C. (2013), "A look at capital measurements in the U. S. and Mexican Economic Censuses", Reality, Data, and Space: International Journal of Statistics and Geography, 4(2), pp. 40-51.

[9] Hendry, D. (2000), Econometrics, Alchemy or Science?, OUP, new edition.

[10] Hickel, J. (2020), Less is More: How Degrowth will Save the World, Penguin Random House.

[11] INEGI (2013), Sistema de Cuentas Nacionales de México. Productividad Total de los Factores 1990-2011, open-access.

[12] Lagunas, S., Oropeza, M. A., and Boggio, J. B. (2020), "Energy consumption in North America: Visualization and pyramidal perspective", Revista Mexicana de Economía y Finanzas, Nueva Época, 15(4), Guest editor: Ilhan Ozturk, Special Issue: Energy and Growth, pp. 709-23. (https://doi.org/10.21919/remef.v15i4.494)

[13] Lequiller, F. and Blades, D. (2014), Understanding National Accounts, second edition, OECD Publishing.

[14] Moreno-Brid, J. C. and Pérez, E. (2003), "Liberalización comercial y crecimiento económico en Centroamérica", CEPAL Review, 81, pp. 157-74. (http://hdl.handle.net/11362/10923)

[15] Moulton, B. R. (2018), The Measurement of Output, Prices, and Productivity: What's Changed Since the Boskin Commission?, The Brookings Institution, open-access.

[16] OECD (2020), Beyond Growth: Towards a New Economic Approach, (https://doi.org/10.1787/a6a5f2eb-en).

[17] Sharif, A., Baris-Tuzemen, O., Uzuner, G., Ozturk, I., and Sinha, A. (2020), "Revisiting the role of renewable and non-renewable energy consumption on Turkey's ecological footprint: Evidence from Quantile ARDL approach", Sustainable Cities and Society, 57(102138), pp. 1-12. (https://doi.org/10.1016/j.scs.2020.102138) 
[18] SHCP (2020), Criterios Generales de Política Económica para la Iniciativa de la Ley de Ingresos y el Proyecto del Presupuesto de Egresos de la Federación Correspondientes al Ejercicio Fiscal 2021, openaccess.

[19] Solow, R. M. (1956), "A contribution to the theory of economic growth", The Quarterly Journal of Economics, 70(1), pp. 65-94. (10.2307/1884513)

[20] Solow, R. M. (1957), "Technical change and the aggregate production function", Review of Economics and Statistics, 39(3), pp. 312-20. (10.2307/1926047)

[21] Solow, R. M. (2005), "Reflections on growth theory", pp. 3-10, Philippe Aghion and Steven Durlauf (editors), Handbook of Economic Growth, Vol. 1A, Elsevier.

[22] Spanos, A. (2003), "Time series and dynamic models", pp. 585-609, Badi H. Baltagi (editor), A Companion to Theoretical Econometrics, Blackwell Publishing.

[23] Valencia-Herrera, H., Santillán-Salagado, R. J., and Venegas-Martínez, F. (2020), "On the interaction among economic growth, energy-electricity consumption, $\mathrm{CO} 2$ emissions, and urbanization in Latin America", Revista Mexicana de Economía y Finanzas, Nueva Época, 15(4), Guest editor: Ilhan Ozturk, Special Issue: Energy and Growth, pp. 745-67. (https://doi.org/10.21919/remef.v15i4.553)

[24] Wackernagel, M., Beyers B., and Rout, K. (2019), Ecological Footprint: Managing Our Biocapacity Budget, the Kindle edition.

[25] Wulf, E. (2020), "Energy, growth and environment: Analysis from the microeconomics perspective", Revista Mexicana de Economía y Finanzas, Nueva Época, 15(4), Guest editor: Ilhan Ozturk, Special Issue: Energy and Growth, pp. 621-45. (https://doi.org/10.21919/remef.v15i4.557)

\section{Statistical annex}

Tests related to equation (2):

\begin{tabular}{|c|c|c|c|}
\hline \multicolumn{4}{|c|}{ Null hypothesis: Individual unit root process } \\
\hline \multicolumn{4}{|c|}{ Series: LOG(NVA), LOG(KMANCU), LOG(HRSMAN), RESID } \\
\hline \multicolumn{4}{|l|}{ Sample: 19902018} \\
\hline \multicolumn{4}{|c|}{ ADF test. Automatic selection of maximum lags } \\
\hline Series & Prob. & Lag & Obs \\
\hline LOG(NVA) & 0.6152 & 0 & 28 \\
\hline LOG(KMANCU) & 0.9183 & 0 & 28 \\
\hline LOG(HRSMAN) & 0.4470 & 0 & 28 \\
\hline RESID & 0.0152 & 0 & 28 \\
\hline $\mathrm{D}(\mathrm{LOG}(\mathrm{NVA}))$ & 0.0001 & 0 & 27 \\
\hline D(LOG(KMANCU) $)$ & 0.0024 & 0 & 27 \\
\hline D(LOG(HRSMAN)) & 0.0002 & 0 & 27 \\
\hline
\end{tabular}




\begin{tabular}{|l|c|c|c|}
\hline Phillips-Perron test. Newey-West automatic bandwidth selection and Bartlett kernel \\
\hline Series & Prob. & Bandwidth & Obs \\
\hline LOG(NVA) & 0.3364 & 20 & 28 \\
\hline LOG(KMANCU) & 0.9132 & 3 & 28 \\
\hline LOG(HRSMAN) & 0.2611 & 4 & 28 \\
\hline RESID & 0.0176 & 3 & 28 \\
\hline D(LOG(NVA)) & 0.0001 & 2 & 27 \\
\hline D(LOG(KMANCU)) & 0.0024 & 1 & 27 \\
\hline D(LOG(HRSMAN)) & 0.0002 & 0 & 27 \\
\hline
\end{tabular}

\begin{tabular}{|l|l|l|l|}
\hline Heteroskedasticity: ARCH & \multicolumn{4}{l|}{} \\
\hline F-statistic & 0.0001 & Prob. F(1,26) & 0.9936 \\
\hline Obs*R-squared & 0.0001 & Prob. Chi-Square(1) & 0.9933 \\
\hline Breusch-Godfrey serial correlation LM test \\
\hline F-statistic & 2.2538 & Prob. F(2,23) & 0.1277 \\
\hline Obs*R-squared & 4.7521 & Prob. Chi-Square(2) & 0.0929 \\
\hline Normality: Jarque-Bera & 0.4976 & Probability & 0.7797 \\
\hline Chi-Square Statistic
\end{tabular}

Tests related to equation (3):

\begin{tabular}{|c|c|c|c|}
\hline \multicolumn{4}{|c|}{ Null hypothesis: RESID has a unit root } \\
\hline \multicolumn{4}{|c|}{ Exogenous: Constant } \\
\hline \multicolumn{4}{|c|}{ Lag length: 3 (Automatic - based on SIC, maxlag=6) } \\
\hline & & t-Statistic & Prob.* \\
\hline $\begin{array}{l}\text { Augmented Dickey- } \\
\text { Fuller }\end{array}$ & & -6.0392 & 0.0000 \\
\hline \multirow[t]{3}{*}{ Test critical values: } & $1 \%$ level & -3.7379 & \\
\hline & $5 \%$ level & -2.9919 & \\
\hline & $10 \%$ level & -2.6355 & \\
\hline
\end{tabular}

\begin{tabular}{|l|l|l|l|}
\hline Heteroskedasticity: ARCH \\
\hline F-statistic & 0.0000 & Prob. F(1,25) & 0.9955 \\
\hline Obs*R-squared & 0.0000 & Prob. Chi-Square(1) & 0.9953 \\
\hline Breusch-Godfrey serial correlation LM test \\
\hline F-statistic & 0.0166 & Prob. F(2,23) & 0.9836 \\
\hline Obs*R-squared & 0.0402 & Prob. Chi-Square(2) & 0.9801 \\
\hline Normality: Jarque-Bera \\
\hline Chi-Square Statistic & 0.4335 & Probability & 0.8051 \\
\hline
\end{tabular}

Tests related to the first VAR model (logs, Manufacturing GDPUS and GDPMX):

VAR lag order selection criteria

Endogenous variables: LOG(GDPMX) LOG(MANUS) 
Exogenous variables: C. Sample: 2005 Q1 2019Q4. Included observations: 55

\begin{tabular}{|c|c|c|c|c|c|c|}
\hline Lag & $\log \mathrm{L}$ & LR & FPE & AIC & SC & $\mathrm{HQ}$ \\
\hline 0 & 163.97 & NA & 0.00 & -5.89 & -5.82 & -5.86 \\
\hline 1 & 254.24 & 170.68 & 0.00 & -9.03 & -8.81 & -8.94 \\
\hline 2 & 282.42 & 51.24 & 0.00 & -9.91 & -9.54 & -9.76 \\
\hline 3 & 284.71 & 4.00 & 0.00 & -9.84 & -9.33 & -9.65 \\
\hline 4 & 309.49 & $41.45^{*}$ & $8.59 \mathrm{e}-08^{*}$ & $-10.59^{*}$ & $-9.94 *$ & $-10.34^{*}$ \\
\hline \multicolumn{7}{|c|}{ * indicates lag order selected by the criterion } \\
\hline \multicolumn{7}{|c|}{ LR: sequential modified LR test statistic (each test at $5 \%$ level) } \\
\hline \multicolumn{7}{|c|}{ FPE: Final prediction error } \\
\hline \multicolumn{7}{|c|}{ AIC: Akaike information criterion } \\
\hline \multicolumn{7}{|c|}{ SC: Schwarz information criterion } \\
\hline \multicolumn{7}{|c|}{ HQ: Hannan-Quinn information criterion } \\
\hline
\end{tabular}

\begin{tabular}{|c|c|c|c|c|}
\hline \multicolumn{5}{|c|}{$\begin{array}{l}\text { VAR stability condition (roots of characteristic } \\
\text { polynomial) }\end{array}$} \\
\hline \multicolumn{5}{|c|}{ Endogenous variables: LOG(GDPMX) LOG(MANUS) } \\
\hline \multicolumn{5}{|c|}{ Exogenous variables: C. Lag specification: 14} \\
\hline Root & \multicolumn{4}{|c|}{ Modulus } \\
\hline 0.990020 & \multicolumn{4}{|c|}{0.990020} \\
\hline \multicolumn{5}{|c|}{ Null hypothesis: no serial correlation at lag order $h$} \\
\hline \multicolumn{5}{|c|}{ Sample: 2005Q1 2019Q4. Included observations: 55} \\
\hline Lags & LM-Stat & \multicolumn{3}{|c|}{ Prob } \\
\hline 1 & 21.48 & \multicolumn{3}{|r|}{0.0003} \\
\hline 2 & 4.08 & \multicolumn{3}{|r|}{0.3950} \\
\hline 3 & 8.62 & \multicolumn{3}{|r|}{0.0714} \\
\hline 4 & 4.09 & \multicolumn{3}{|c|}{0.3946} \\
\hline \multicolumn{5}{|c|}{ VAR residual heteroskedasticity: Includes cross terms } \\
\hline \multicolumn{5}{|c|}{ Joint test: } \\
\hline Chi-sq & $\mathrm{df}$ & \multicolumn{3}{|r|}{ Prob. } \\
\hline 144.96 & 132 & \multicolumn{3}{|r|}{0.2079} \\
\hline \multicolumn{5}{|c|}{ VAR residual normality } \\
\hline \multicolumn{5}{|c|}{ Orthogonalization: Cholesky (Lutkepohl) } \\
\hline \multicolumn{5}{|c|}{ Null Hypothesis: residuals are multivariate normal } \\
\hline Component & Skewness & Chi-sq & $\mathrm{df}$ & Prob. \\
\hline 1 & -0.3788 & 1.3150 & 1 & 0.2515 \\
\hline 2 & -0.0703 & 0.0453 & 1 & 0.8314 \\
\hline Joint & & 1.3603 & 2 & 0.5065 \\
\hline
\end{tabular}

Tests related to the second VAR model (logs, FOOTPRINT and GDPMX):

\section{VAR Lag Order Selection Criteria}

Endogenous variables: LOG(FOOTPRINT) LOG(GDPMX)

Exogenous variables: C. Sample: 1960 2019. Included observations: 54 


\begin{tabular}{|c|c|c|c|c|c|c|} 
Lag & Log L & LR & FPE & AIC & SC & HQ \\
\hline 0 & 15.4871 & NA & 0.00208 & -0.499522 & -0.425856 & -0.471112 \\
\hline 1 & 200.0248 & $348.5713^{*}$ & $2.60 \mathrm{e}-06^{*}$ & $-7.186105^{*}$ & $-6.965107^{*}$ & $-7.100875^{*}$ \\
\hline 2 & 203.3969 & 6.119758 & $2.66 \mathrm{E}-06$ & -7.16285 & -6.794519 & -7.020799 \\
\hline 3 & 203.7568 & 0.626403 & $3.05 \mathrm{E}-06$ & -7.028029 & -6.512367 & -6.829159 \\
\hline
\end{tabular}

\begin{tabular}{|c|c|c|c|c|}
\hline $\begin{array}{l}\text { VAR stabilit } \\
\text { polynomial) }\end{array}$ & condition & (roots of $\mathrm{c}$ & & \\
\hline Endogenous & variables: L & OG(FOOTPF & ) L & $\mathrm{MX})$ \\
\hline Exogenous v & ariables: C. I & ag specific & : 1 & \\
\hline Root & & & & \\
\hline 0.972747 & & & 747 & \\
\hline 0.824779 & & & 779 & \\
\hline VAR Residu & a Serial Co & rrelation L & est & \\
\hline Null Hypothe & sis: no seria & l correlatio & lag & \\
\hline Sample: 196 & 2019. Incl & uded observ & ons: & \\
\hline Lags & LM-Stat & & & \\
\hline 1 & 6.764502 & & & \\
\hline 2 & 0.536357 & & & \\
\hline 3 & 7.713698 & & & \\
\hline VAR Residu & l Normalit & & & \\
\hline Orthogonaliz & ation: Chole & sky (Lutkep & & \\
\hline Null Hypothe & sis: residua & Is are multi & ate & \\
\hline Sample: 196 & 2019. Incl & ded observ & ons: & \\
\hline Component & Skewness & Chi-sq & $\mathrm{df}$ & Prob. \\
\hline 1 & 0.803333 & 6.023208 & 1 & 0.0141 \\
\hline 2 & $\begin{array}{c}- \\
0.972673 \\
\end{array}$ & 8.830202 & 1 & 0.003 \\
\hline Joint & & 14.85341 & 2 & 0.0006 \\
\hline VAR Residu & l Heterosk & edasticity & & \\
\hline Sample: 196 & 2019. Inclu & Ided observ & 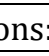 & \\
\hline Joint test: & & & & \\
\hline Chi-sq & $\mathrm{df}$ & & & \\
\hline 15.23371 & 12 & & & \\
\hline
\end{tabular}

\begin{tabular}{|c|c|c|c|c|}
\hline \multicolumn{5}{|c|}{ Sample (adjusted): 19622016} \\
\hline \multicolumn{5}{|c|}{ Included observations: 55 after adjustments } \\
\hline \multicolumn{5}{|c|}{ Trend assumption: No deterministic trend } \\
\hline \multicolumn{5}{|c|}{ Series: LOG(FOOTPRINT) LOG(GDPMX) } \\
\hline \multicolumn{5}{|c|}{ Lags interval (in first differences): 1 to 1} \\
\hline \multicolumn{5}{|c|}{ Unrestricted Cointegration Rank Test (Trace) } \\
\hline Hypothesized & & Trace & & \\
\hline No. of CE(s) & Eigenvalue & Statistic & Critical Value & Prob.** \\
\hline None ${ }^{*}$ & 0.311708 & 20.86519 & 12.3209 & 0.0015 \\
\hline At most 1 & 0.005808 & 0.320359 & 4.129906 & 0.6335 \\
\hline
\end{tabular}


Trace test indicates 1 cointegrating eqn(s) at the 0.05 level

$*$ denotes rejection of the hypothesis at the 0.05 level

**MacKinnon-Haug-Michelis (1999) p-values

\begin{tabular}{|l|c|c|c|c|}
\hline Unrestricted Cointegration Rank Test (Maximum Eigenvalue) \\
\hline Hypothesized & & Max-Eigen & & \\
\hline No. of CE(s) & Eigenvalue & Statistic & Critical Value & Prob.** \\
\hline None * & 0.311708 & 20.54483 & 11.2248 & 0.0009 \\
\hline At most 1 & 0.005808 & 0.320359 & 4.129906 & 0.6335 \\
\hline Max-eigenvalue test indicates 1 cointegrating eqn(s) at the 0.05 level \\
\hline * denotes rejection of the hypothesis at the 0.05 level \\
\hline **MacKinnon-Haug-Michelis (1999) p-values \\
\hline $\begin{array}{l}\text { Normalized cointegrating coefficients (standard error in } \\
\text { parentheses) }\end{array}$ \\
\hline LOG(FOOTPRINT) & \multicolumn{5}{|c|}{ LOG(GDPMX) } \\
\hline \multicolumn{5}{|c|}{-1.170542} \\
\hline 1 & -0.00537 \\
\hline
\end{tabular}

\begin{tabular}{|c|c|c|c|c|}
\hline \multicolumn{5}{|c|}{ Sample (adjusted): 19642016} \\
\hline \multicolumn{5}{|c|}{ Included observations: 53 after adjustments } \\
\hline \multicolumn{5}{|c|}{ Trend assumption: No deterministic trend } \\
\hline \multicolumn{5}{|c|}{ Series: LOG(FOOTPRINT) LOG(GDPMX) } \\
\hline \multicolumn{5}{|c|}{ Lags interval (in first differences): 1 to 3} \\
\hline \multicolumn{5}{|c|}{ Unrestricted Cointegration Rank Test (Trace) } \\
\hline Hypothesized & & Trace & & \\
\hline No. of CE(s) & Eigenvalue & Statistic & Critical Value & Prob.** \\
\hline None* & 0.295785 & 19.2493 & 12.3209 & 0.003 \\
\hline At most 1 & 0.012444 & 0.66369 & 4.129906 & 0.4753 \\
\hline \multicolumn{5}{|c|}{ Trace test indicates 1 cointegrating eqn(s) at the 0.05 level } \\
\hline \multicolumn{5}{|c|}{$*$ denotes rejection of the hypothesis at the 0.05 level } \\
\hline \multicolumn{5}{|c|}{ **MacKinnon-Haug-Michelis (1999) p-values } \\
\hline \multicolumn{5}{|c|}{ Unrestricted Cointegration Rank Test (Maximum Eigenvalue) } \\
\hline Hypothesized & & Max-Eigen & & \\
\hline No. of CE(s) & Eigenvalue & Statistic & Critical Value & Prob.** \\
\hline None * & 0.295785 & 18.58561 & 11.2248 & 0.0022 \\
\hline At most 1 & 0.012444 & 0.66369 & 4.129906 & 0.4753 \\
\hline \multicolumn{5}{|c|}{ Max-eigenvalue test indicates 1 cointegrating eqn(s) at the 0.05 level } \\
\hline \multicolumn{5}{|c|}{$*$ denotes rejection of the hypothesis at the 0.05 level } \\
\hline \multicolumn{5}{|c|}{ **MacKinnon-Haug-Michelis (1999) p-values } \\
\hline \multicolumn{5}{|c|}{$\begin{array}{l}\text { Normalized cointegrating coefficients (standard error in } \\
\text { parentheses) }\end{array}$} \\
\hline LOG(FOOTPRINT) & \multicolumn{4}{|c|}{ LOG(GDPMX) } \\
\hline 1 & \multicolumn{4}{|c|}{-1.175346} \\
\hline & \multicolumn{4}{|c|}{-0.00425} \\
\hline
\end{tabular}

